\title{
A Study on Genetic Differentiation and Phylogenetic Relationships among East Asian Titmice (Family Paridae) and Relatives
}

\author{
Noriko Ohta ${ }^{1,2}$, Seiji Kusuhara ${ }^{1}$ and Ryozo Kakizawa ${ }^{2}$
}

1 Graduate School of Science and Technology, Niigata University. Ninomachi 8050, Igarashi, Niigata-shi, Niigata 950-2181, Japan

2 Yamashina Institute for Ornithology, Konoyama 115, Abiko-shi, Chiba 270-1145, Japan

By means of protein electrophoresis on 23 loci (15 enzymes), genetic variation and differentiation among eight East Asian Titmice (family Paridae, genus Parus), two long-tailed tits (family Aegithalidae, genus Aegithalos), a nuthatch (family Sittidae, Sitta) and Bearded Tit (family Paradoxornithidae, genus Panurus) were analyzed. A genealogic dendrogram is constructed by the UPGMA method, using genetic distances among the species. The results of the present study suggests that the East Asian Parus species investigated can be divided into four groups, i.e., groups consisting of (1) Parus montanus, (2) P. ater, P. venustulus and $P$. varius, (3) P. major and $P$. monticolus, and (4) P. spilonotus and $P$. holsti. $P$. spilonotus seems to have a close relationship to $P$. holsti, but distant relationships to P. major and P. monticolus. Aegithalos, Sitta and Panurus are relatively closely related to each other, whereas the Parus species are shown to have a family level genetic distance in the Passeriformes.

In this study, we could not get enough samples of some species (especially $P$. montanus and $P$. spilonotus). And since we obtained samples from dealers, there are some possibility that samples were collected from only one population of each species. The data of other samples from several populations and that of other species are needed to determine the phylogeny of the East Asian Parus species.

Key Words: East Asian Titmice, Isozyme, Paridae, Parus, Phylogeny

Titmice (family Paridae) are small birds which inhabit the forests of Africa, Europe, Asia and North America. They are very acrobatic in clinging to branches by their feet and have relatively short beaks and stout feet. Snow (1967) classified 46 species of the Paridae into three genera without recognizing subgenera: Parus (44 species), Melanochlora (1 species), and Sylviparus (1 species). His classification has been accepted widely at the present, whereas Thielcke (1968) classified 43 species of Parus into 10 subgenera. We follow Thielcke in recognition of subgenera of Parus. Fourteen Parus species that belong to 8 subgenera are distributed in East Asia (Mongolia, China, the Korean Peninsula, Taiwan and Japan).

In earlier studies, Vaurie $(1950,1957)$ discussed the taxonomic problems and relationships of Palearctic species of the Paridae using morphological characters, but the phylogenetic relationships of Asian titmice are still poorly known. 
Recently there have been systematic studies of the Paridae in Europe and North America based on isozymes and DNA analysis (Gill et al. 1989, Sheldon et al. 1992; Kvist et al. 1996, Slikas et al. 1996). However, there are no comparable studies on Asian species, which makes a study of Asian titmice desirable.

The Aegithalidae, Sittidae and Paradoxornithidae (Panurus) are considered to be closely related to the Paridae. Aegithalos and a few related genera have been treated as a separate family, the Aegithalidae (Snow, 1967), but they are often considered as genera or a subfamily of the Paridae (e.g., Hellmayr 1903, Mayr \& Amandon 1951). Panurus has been classified in the subfamily Panurinae (=Paradoxornithinae) of the family Muscicapidae (s. lat.) (Deignan 1964). In addition, the Sittidae have sometimes been considered as a subfamily of the Paridae (Vaurie 1959).

This study attempts to reveal the phylogenetic relationships among the little studied members of the Paridae of East Asia and their relationships to Aegithalos, Sitta and Panurus. These species were examined by electrophoretic analysis on 23 loci (15 enzymes) with tissues (liver, muscle and heart) taken from 59 individual birds.

\section{MATERIALS AND METHODS}

We analyzed 59 individual birds belonging to 6 subgenera and 8 species of the Paridae, one species of the Paradoxornithinae, two species of the Aegithalidae, and one species of the Sittidae. They were obtained from pet dealers between March 1986 and May 1997, so detailed locality and population number of the samples are not known. The species, sample sizes and localities of the samples used in this study are given in Table 1 . The liver, muscles and heart were removed from half-

Table 1. Studied species, sample size and locality.

\begin{tabular}{lllcl}
\hline \hline \multicolumn{1}{c}{ Family } & \multicolumn{1}{c}{ Species } & English name & $\begin{array}{c}\text { Sample } \\
\text { size }\end{array}$ & Locality \\
\hline Paradoxornithidae & Panurus biarmicus & Bearded Tit & 2 & China \\
Aegithalidae & Aegithalos caudatus & Long-tailed Tit & 3 & China \\
& Aegithalos concinnus & Red-headed Tit & 2 & Taiwan \\
Paridae & Parus (Poecile) montanus & Willow Tit & 1 & China \\
& Parus (Periparus) ater & Coal Tit & 7 & Taiwan \\
& Parus (Pardaliparus) venustulu & Yellow-bellied Tit & 12 & China \\
& Parus (Parus) major & Great Tit & 7 & China \\
& Parus (Parus) monticolus & Green-backed Tit & 11 & Taiwan \\
& Parus (Parus) spilonotus & Chinese Yellow Tit & 2 & China \\
Sittidae & Parus (Machlolophus) holsti & Formosan Yellow Tit & 6 & Taiwan \\
Total & Parus (Sittiparus) varius & Varied Tit & 5 & Taiwan \\
& Sitta europaea & Nuthatch & 1 & China \\
\hline 12 species & & 51 individuals & \\
\hline
\end{tabular}

Order of the species follow Snow (1967), Deignan (1964) and Thielcke (1968). The subgenera of Parus after Thielcke (1968) are given in parenthesis. 
defrosted birds, homogenized, and centrifuged at $15,000 \times \mathrm{g}$ for 20 minutes at $2{ }^{\circ} \mathrm{C}$. The supernatant was then divided into aliquots and stored in capillary glass tubes at $-80^{\circ} \mathrm{C}$. The extracts of the tissues were analyzed by starch gel electrophoresis to determine the allelic composition of each protein locus. The combinations of tissues and buffer systems for enzyme detection are shown in Table 2. The staining

Table 2. Combinations of tissues and buffer systems for detection of enzymes.

\begin{tabular}{llll}
\hline \hline \multicolumn{1}{c}{ Protein } & Abbr. & \multicolumn{1}{c}{ Tissues } & \multicolumn{1}{c}{ Buffers ${ }^{*}$} \\
\hline Creatine kinase & CK & Muscle, Heart & Tris-HCl \\
Diaphorase & DIA & Liver & Tris-HCl \\
Esterase-D & ESD & Liver & Tris-citrate \\
Glutamate oxaloacetate transaminase & GOT & Liver & Tris-citrate \\
$\alpha$-Glycerophosphate dehydrogenase & $\alpha$-GPDH & Muscle & Tris-citrate \\
Glucosephosphate isomerase & GPI & Muscle & Tris-citrate \\
Isocitrate dehydrogenase & IDH & Liver & Tris-citrate \\
Lactate dehydrogenase & LDH & Muscle, Heart & Tris-citrate \\
Malate dehydrogenase & MDH & Liver & Tris-citrate \\
Peptidase & PEP & Liver & Poulik \\
6-Phosphoglucose dehydrogenase & 6PGD & Liver & Tris-citrate \\
Phosphoglucosemutase & PGM & Liver & Tris-citrate \\
General protein & PT & Muscle & Tris-citrate \\
Sorbitol dehydrogenase & SDH & Liver & Tris-citrate \\
Superoxide dismutase & SOD & Liver & Tris-citrate \\
\hline
\end{tabular}

*Tris-HCl, Poulik: Selander et al. (1971), Tris-citrate: Numachi et al. (1983).

method for enzymes were essentially the same as those described by Bell et al. (1982), Shaw \& Prasad (1970), Selander et al. (1971), Hopkinson et al. (1973) and Numachi et al. (1979). These enzymes and proteins are assumed to be coded by 23 gene loci. Allozymes representing alleles for individual loci are designated alphabetically in decreasing order of mobility. Isozyme systems under the control of distinct loci were identified numerically, counting from the anodal side.

Genetic differentiations in populations, both the proportion of polymorphic loci and heterozygosities, were calculated as follows. The proportion of polymorphic loci were identified as the proportion of genetic loci that showed variations. Heterozygosities were calculated in two ways: observed heterozygosities were calculated by averaging the proportion of individual heterozygous birds observed per locus, and expected heterozygosities were calculated as the proportion of heterozygosities expected from allele frequencies, assuming Hardy-Weinberg equilibria. Genetic identities and genetic distances between species were calculated using Nei' s (1972) formula, and the values of genetic distances were clustered into a dendrogram using the unweighted pair-group method of analysis with arithmetic means (UPGMA) (Sneath \& Sokal 1973). 


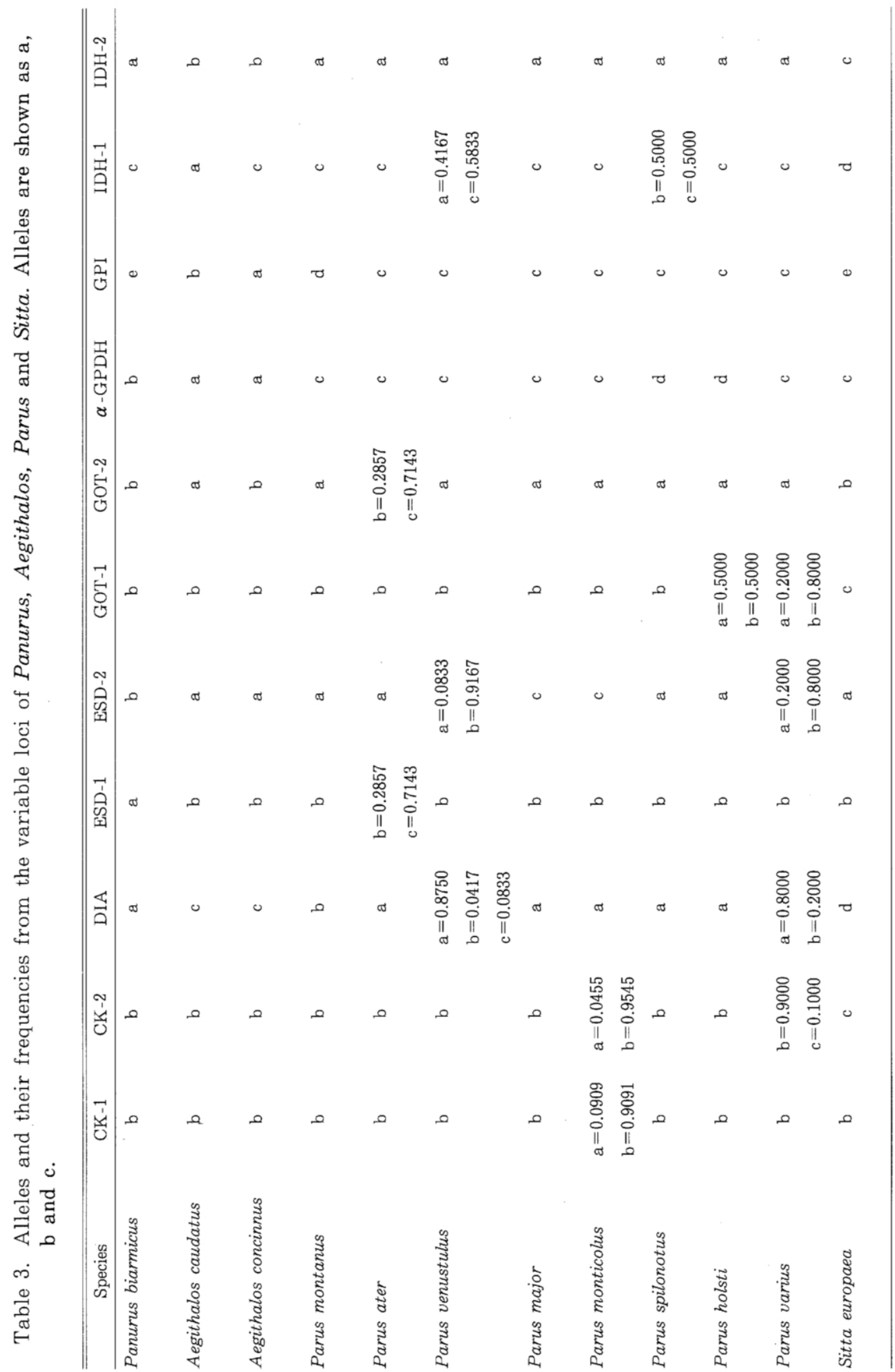




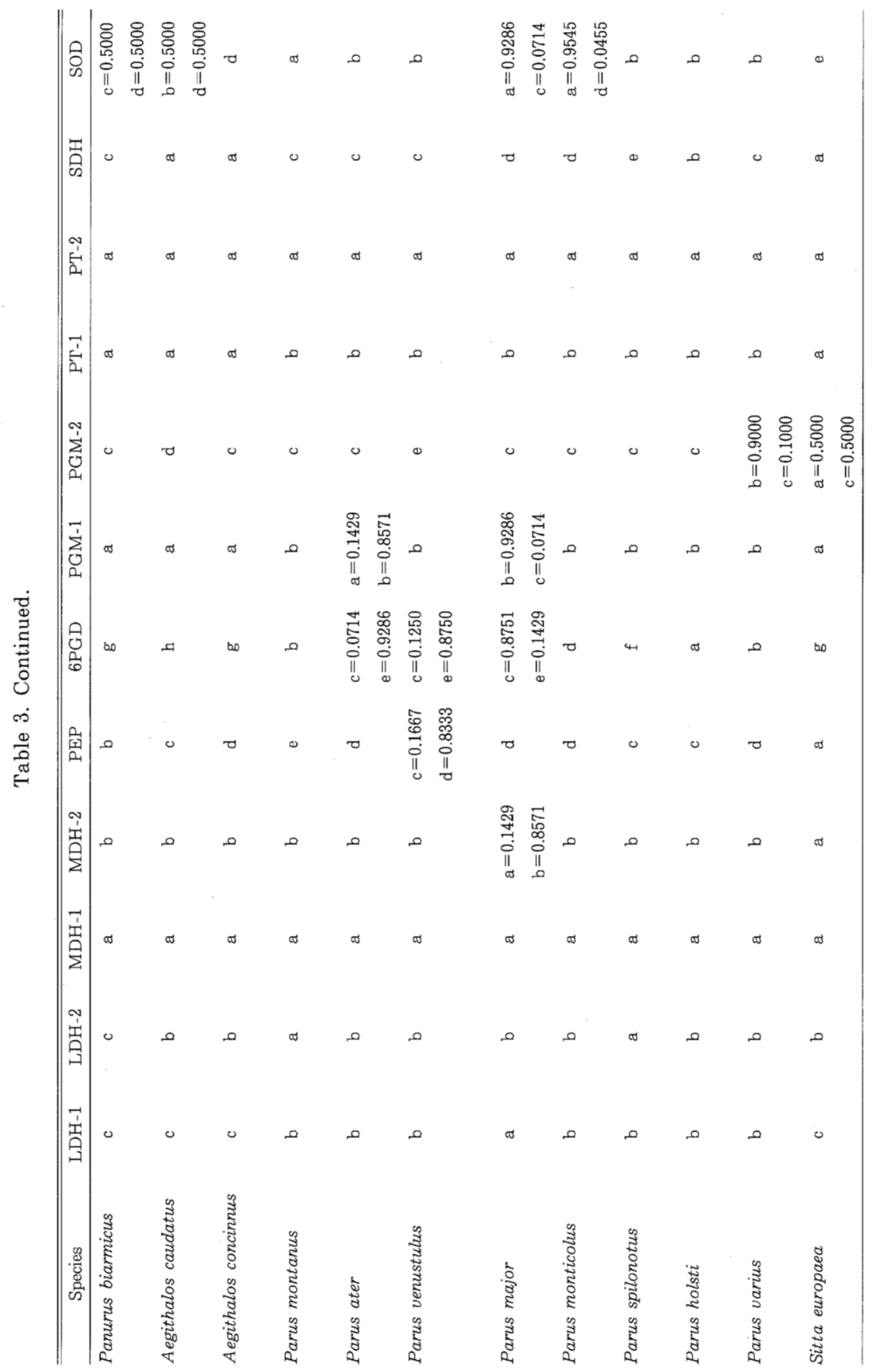




\section{RESULTS}

\section{1) Genetic variation}

Alleles detected at each locus and the frequency of allele occurrences are shown in Table 3. The number of birds investigated for each species ranged from one to twelve, with intraspecific genetic variations found in all species of Parus studied except $P$. montanus, of which there was only one specimen. No intraspecific genetic variation was detected in both species of Aegithalos and Panurus tested (Sitta was represented by one specimen).

The species with the highest genetic variation was $P$. venustulus and $P$. varius, which showed variations at 5 loci. Fourteen loci showed genetic variations within a species: SOD (variation found in four species), 6PGD (three species), CK-2, DIA, ESD-2, GOT-1, IDH-1, PGM-1 and PGM-2 (two species), CK-1, ESD-1, GOT-2, MDH-2, and PEP (one species). The largest number of alleles found at any one locus was eight at 6PGD.

The proportions of polymorphic loci and average heterozygosities (observed and expected) of the species studied are shown in Table 4 and those data for other avian groups are shown in Table 5. The mean proportion of polymorphic loci of the 8 species of Parus was 0.125 (range $0-0.217$ ), which is relatively lower than

Table 4. Proportion of polymorphic loci and heterozygosities (observed and expected) of each species.

\begin{tabular}{lccc}
\hline \multicolumn{1}{c}{ Species } & $\begin{array}{c}\text { Proportion of } \\
\text { polymorphic loci }\end{array}$ & \multicolumn{2}{c}{ Average heterozygosity } \\
\cline { 3 - 4 } Paradoxornithidae & & Observed & Expected \\
$\quad$ Panurus biarmicus & 0.043 & 0.043 & 0.022 \\
Aegithalidae & & & \\
$\quad$ Aegithalos caudatus & 0.043 & 0.043 & 0.022 \\
Aegithalos concinnus & 0 & 0 & 0 \\
$\quad$ Aegithalidae Mean & 0.022 & 0.022 & 0.011 \\
Paridae & & & \\
Parus montanus & 0 & 0 & 0 \\
Parus ater & 0.174 & 0.031 & 0.052 \\
Parus venustulus & 0.217 & 0.018 & 0.059 \\
Parus major & 0.174 & 0.025 & 0.033 \\
Parus monticolus & 0.130 & 0.008 & 0.015 \\
Parus spilonotus & 0.043 & 0 & 0.022 \\
Parus holsti & 0.043 & 0.029 & 0.022 \\
Parus varius & 0.217 & 0.035 & 0.057 \\
$\quad$ Paridae Mean & 0.125 & 0.018 & 0.033 \\
Sittidae & & & \\
Sitta europaea & 0.043 & 0.043 & 0.022 \\
\hline
\end{tabular}


Table 5. Proportion of polymorphic loci and expected heterozygosities in various groups of birds.

\begin{tabular}{|c|c|c|c|c|}
\hline Taxon & Loci & $\begin{array}{l}\text { Proportion of } \\
\text { polymorphic loci }\end{array}$ & $\begin{array}{c}\text { Expected } \\
\text { Average heterozygosity }\end{array}$ & Source \\
\hline \multicolumn{5}{|l|}{ Non-Passeriformes } \\
\hline Phasianidae (Gallus) & 32 & 0.125 & 0.046 & Ohta et al. (in press) \\
\hline Phasianidae & 23 & 0.184 & 0.045 & Gutiérrez et al. (1983) \\
\hline Procellariiformes & 23 & - & 0.003 & Kuroda et al. (1990) \\
\hline Anatidae & 10 & 0.019 & 0.003 & Numachi et al. (1983) \\
\hline Alcidae & 24 & 0.045 & 0.017 & Watada et al. (1987) \\
\hline Mean & & 0.093 & 0.023 & \\
\hline \multicolumn{5}{|l|}{ Passeriformes } \\
\hline Mimidae & 23 & 0.009 & 0.015 & Avise et al. (1982) \\
\hline Muscicapidae & $25 \sim 27$ & 0.167 & 0.043 & Avise et al. (1980a) \\
\hline Paridae & 23 & 0.125 & 0.033 & Present study \\
\hline Emberizidae & $20 \sim 21$ & 0.151 & 0.039 & Avise et al. (1980b) \\
\hline Emberizidae & 20 & 0.140 & 0.042 & Watada et al. (1995) \\
\hline Parulidae & $16 \sim 22$ & 0.392 & 0.134 & Barrowclough \& Corbin (1978) \\
\hline Vireonidae & 23 & 0.115 & 0.036 & Avise et al. (1982) \\
\hline Estrildidae & 26 & 0.061 & 0.017 & Kakizawa \& Watada (1985) \\
\hline Mean & & 0.145 & 0.045 & \\
\hline
\end{tabular}

for the Passeriformes (0.145).

Of the 23 loci tested, inter-specific variations were found in 19 loci (CK-1, CK-2, DIA, ESD-1, ESD-2, GOT-1, GOT-2, $\alpha$-GPDH, GPI, IDH-1, LDH-1, LDH-2, MDH-2, PEP, 6PGD, PGM-1, PGM-2, SDH and SOD) in the 8 species of Parus. LDH-1 showed a single allele except in $P$. major.

Inter-specific variations of two Aegithalos species were found in 7 loci (GOT-2, GPI, IDH-1, PEP, 6PGD, PGM-2 and SOD).

Genetic variations between Parus, Aegithalos, Sitta and Panurus were found in 21 loci (CK-1, CK-2, DIA, ESD-1, ESD-2, GOT-1, GOT-2, $\alpha$-GPDH, GPI, IDH-1, IDH-2, LDH-1, LDH-2, MDH-2, PEP, 6PGD, PGM-1, PGM-2, PT-1, SDH and SOD). IDH-2 showed a single allele in Parus and Panurus and PT-1 showed a single allele in Aegithalos, Sitta and Panurus.

2) Genetic differentiation

The genetic identity and distances were calculated from the data given in Table 6 according to Nei's (1972) formula. The results obtained from the analysis of the 23 loci showed that genetic variation was found among all the species of Parus, Aegithalos, Sitta and Panurus examined. The lowest genetic distance was found between $P$. major and $P$. monticolus (0.0892), and the second lowest one between $P$. venustulus and $P$. varius $(0.1012)$. These values probably indicate relatively low 


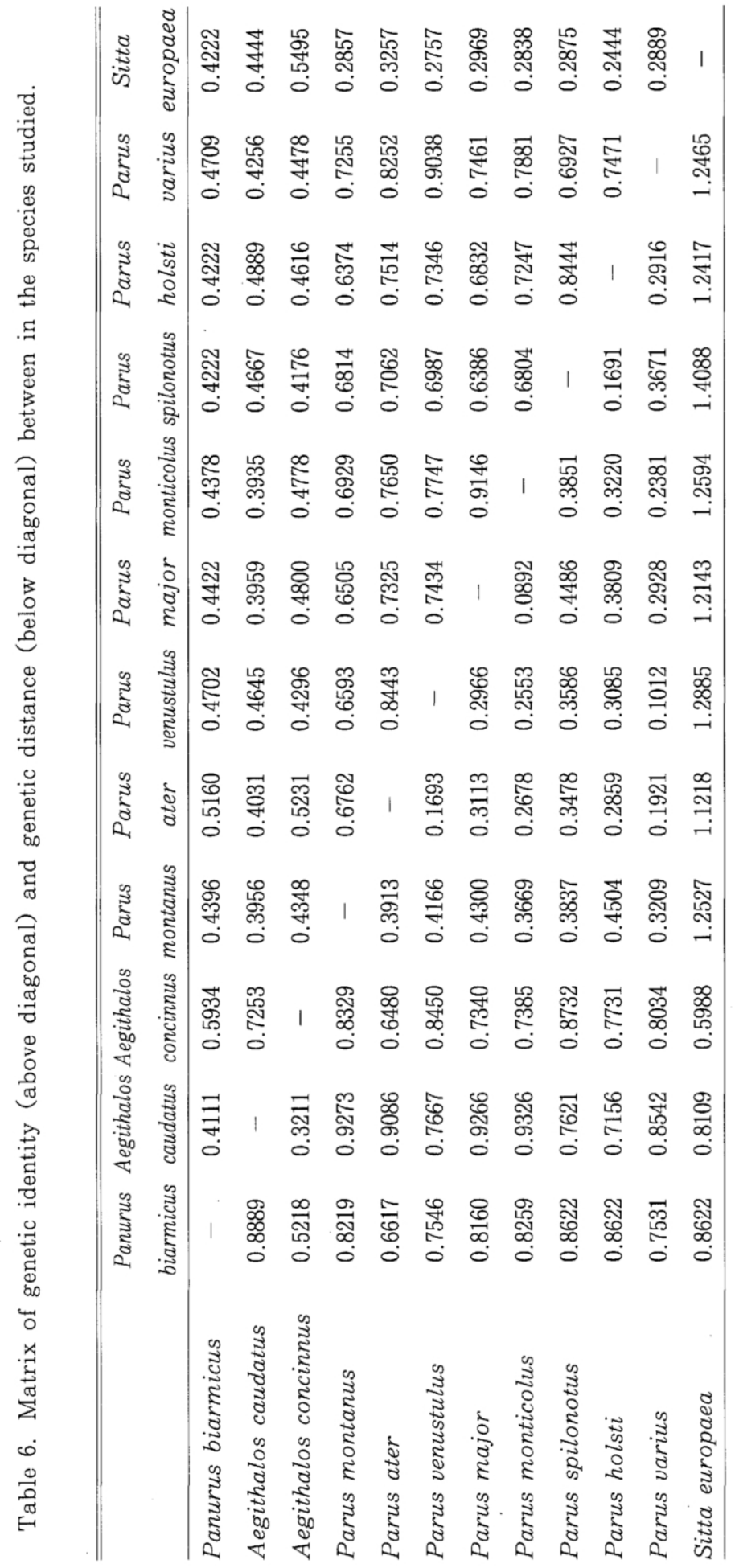


genetic differentiation between the two species, respectively. The highest genetic distance (1.4088) was found between P. spilonotus and Sitta europaea. Among the Parus studied, the highest genetic distance (0.4504) occurred between P. montanus and $P$. holsti. The mean genetic distances of avian taxa at various levels of taxonomic divergency are shown in Table 7 . This shows an average genetic distance at

Table 7. Mean genetic distances in avian taxa at various levels of taxonomic divergence.

\begin{tabular}{|c|c|c|c|c|c|}
\hline Taxon & Subspecies & Species & Genus & Family & Source \\
\hline \multicolumn{6}{|l|}{ Non-Passeriformes } \\
\hline Phasianidae & - & 0.092 & - & - & Ohta et al. (in press) \\
\hline Procellariiformes & - & 0.137 & 0.350 & 0.554 & Kuroda et al. (1990) \\
\hline Procellariiformes & - & - & 0.435 & 0.683 & Barrowclough et al. (1981) \\
\hline Anatidae & 0.000 & 0.016 & 0.285 & 0.674 & Numachi et al. (1983) \\
\hline Alcidae & - & 0.151 & 0.442 & - & Watada et al. (1987) \\
\hline Non-Passeriformes Mean & 0.000 & 0.099 & 0.378 & 0.637 & \\
\hline \multicolumn{6}{|l|}{ Passeriformes } \\
\hline Mimidae & - & 0.084 & 0.223 & - & Avise et al. (1982) \\
\hline Muscicapidae and Mimidae & - & 0.024 & 0.344 & 0.780 & Avise et al. (1980a) \\
\hline Emberizidae and Fringillidae & 0.009 & 0.123 & 0.253 & 0.592 & Avise et al. (1980b) \\
\hline Emberizidae & - & 0.331 & 0.617 & - & Watada et al. (1995) \\
\hline Paridae & - & 0.309 & - & 0.955 & Present study \\
\hline Parulidae & - & 0.100 & 0.179 & - & Barrowclough \& Corbin (1978) \\
\hline Parulidae & - & 0.060 & 0.175 & 0.998 & Avise et al. (1980c) \\
\hline Vireonidae & - & 0.360 & - & - & Avise et al. (1982) \\
\hline Icteridae & - & 0.011 & 0.248 & - & Smith et al. (1976) \\
\hline Estrildidae & 0.001 & 0.193 & 0.397 & - & Kakizawa \& Watada (1985) \\
\hline Sturnidae & 0.007 & 0.035 & 0.397 & - & Corbin et al. (1974) \\
\hline Passeriformes Mean & 0.006 & 0.148 & 0.315 & 0.831 & \\
\hline
\end{tabular}

species level is 0.148 for the Passeriformes and 0.099 for the non-Passeriformes. The mean genetic distance of the 8 Parus species studied was 0.309 , which was almost twice the mean genetic distance of the Passeriformes (0.148). Genetic distance between Aegithalos caudatus and A. concinnus was 0.3211, which is somewhat higher than in the Parus species.

3) Genetic relationships in Asian Parus

By means of the UPGMA procedure, a genealogic dendrogram (Fig. 1) was constructed, based on values for inter-specific distances within the species here analyzed. The dendrogram shows that the 8 species of Parus can be classified into four groups, the first group consisting of Parus montanus, the second P. ater, $P$. venustulus and $P$. varius, the third $P$. major and $P$. monticolus, and the fourth $P$. 


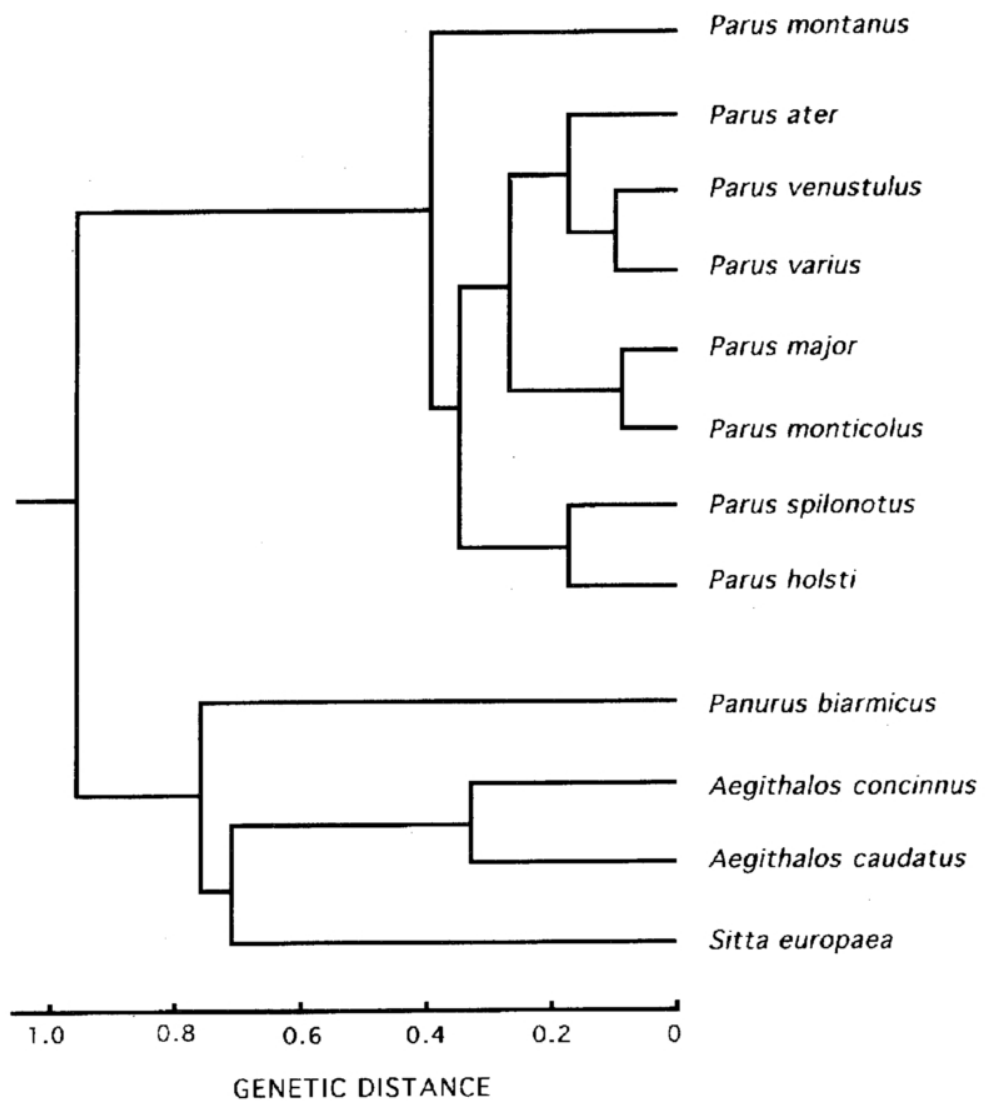

Fig. 1. Dendrogram of the East Asian Paridae, Panurus, Aegithalos and Sitta based on Nei's genetic distance at 23 loci derived by the UPGMA method.

spilonotus and $P$. holsti. The genetic distance between $P$. ater- $P$. venustulus- $P$. varius group and $P$. major- $P$. monticolus group is 0.2770 . The value between $P$. spilonotus- $P$. holsti group and $P$. ater- $P$. venustulus- $P$. varius- $P$. major- $P$. monticolus group (0.3496) and that between these groups and $P$. montanus (0.3943) are greater than the genus level genetic distance for the Passeriformes (0.315).

As to the genetic distances among Aegithalos, Sitta, Panurus and the 8 species of Parus, the closest is found to be between Aegithalos and Sitta, and Panurus is closer to Aegithalos and Sitta than Parus. On the other hand, all Parus species are more distant to Aegithalos, Sitta and Panurus than to each other.

\section{DISCUSSION}

1) Genetic variation and differentiation intra-speicies of East Asian Parus In this study, the mean expected heterozygosity of the 8 Parus species (0.033) is 
relatively lower than the value for the Passeriformes (0.045) (Table 5), and is 1.8 times the mean observed heterozygosity (0.018). However, we examined only a few individuals of $P$. montanus ( 1 individual) and $P$. spilonotus ( 2 individuals), the mean expected heterozygosity of the 6 Parus species except these two species (0.040) is almost same of the value for the Passeriformes. We obtained all of the samples from dealers, and there is a possibility that the samples of each species were collected from only one population.

\section{2) Genetic variation and differentiation inter-species of East Asian Parus}

Hellmayr (1903) recognized 11 subgenera for Parus by plumage pattern. According to him, the eight species investigated in this study belong to 6 subgenera: Poecile ( $P$. montanus), Periparus ( $P$. ater), Pardaliparus ( $P$. venustulus), Sittiparus ( $P$. varius), Machlolophus ( $P$. spilonotus, $P$. holsti) and Parus ( $P$. major, P. monticolus). P. spilonotus and P. holsti in the subgenus Machlolophus have a prominent crest. $P$. varius of the subgenus Sittiparus is monotypic, whereas $P$. major and P. monticolus were placed in the subgenus Parus. Both $P$. ater (subgenus Periparus) and $P$. venustulus (subgenus Pardaliparus) have a pale color patch on the neck or upper back, but the underparts are white or pale color in $P$. ater and bright yellow in $P$. venustulus. $P$. montanus, together with $P$. palustris, is in the own subgenus Poecile. This study supports a close relationship between $P$. major and $P$. monticolus and that between $P$. spilonotus and $P$. holsti respectively, in agreement with Hellmayr's classification. On the other hand, $P$. ater, $P$. venustulus and $P$. varius, which are probably closely related as suggested by the present study, were placed in three separate subgenera in Hellmayr's classification.

Wolters (1982) classified the family Paridae into 11 genera. He considered the subgenus Sittiparus (containing P. varius), Periparus (containing $P$. ater) and Pardaliparus (containing $P$. venustulus) forming a genus Periparus, separated from genera Poecile and Parus. These three subgenera formed a closely related group in our study, which agrees with Wolters's classification.

Since the genetic distance between the $P$. spilonotus- $P$. holsti group and the $P$. ater- $P$. venustulus- $P$. varius- $P$. major- $P$. monticolus group, and the distance between these two groups and $P$. montanus, are greater than the genus level genetic distance for Passeriformes, the $P$. spilonotus- $P$. holsti group and $P$. montanus may have diverged from the other groups relatively early in this family history.

Sheldon et al. (1992) and Slikas et al. (1996) studied phylogeny of the Paridae using DNA-DNA hybridization and stated that "the genetic divergence among tit species is much greater than expected for such similar-looking birds" and "the genetic distance between members of the Parus/Cyanistes subgenetic clade and other parid are remarkably large for bird congeners". Following Slikas et al. (1996) Check-list of North-American Birds (AOU. 1998) ranked Poecile and Baeolophus as separate genera. In our study, Poecile ( $P$. montanus) and Machlolophus ( $P$. spilonotus and $P$. holsti) showed the genus level genetic distances to other groups of the Paridae examined and we believe that these two genera should be recognized.

However the placement of $P$. montanus was not confirmed since only one individual specimen was available for this study. Data of another individuals are needed to determine the exact phylogenetic position of this species. As we obtained all of the samples from dealers, there is a possibility that the samples of each species 
were collected from only one population. Also the data of other samples from several populations are needed to determine the phylogeny of the East Asian Parus species.

3) Relationships of Aegithalos, Sitta and Panurus

Aegithalos was at one time classified in the family Paridae (Gadow 1883, Hellmayr 1903, Mayr \& Amandon 1951), but is now treated as a separate family (Snow 1967). Stresemann (1923) called attention to the fact that the Aegithalidae has some characteristics (presence of a complete juvenile-molt, nest structure, naked hatching, etc.) which differ from those of the Paridae. The genetic distance between Aegithalos and Parus appears to be at familial level (Table 5) and the present classification is supported by our study.

Sheldon \& Gill (1996) studied phylogeny of song birds using DNA-DNA hybridization and concluded that the sister group of the seed-caching Paridae is the Remizidae (including Verdin Auriparus), whereas the Paridae may not be closely related to the Aegithalidae, Certhiidae and Sittidae which were placed close to them in traditional classification. Our study also shown that Parus are not so closely related to Sitta, Aegithalos and Panurus.

In this study, Panurus is found to be relatively closely related to Aegithalos and Sitta. Panurus was classified in Parus by Linné (1758), though most recent classifiers considered it to be related either to the Timaliidae or Paradoxornithidae (= Panurinae) (e.g., Mayr \& Amandon 1951, Vaurie 1959, Deignan 1964, Beaman 1994). Gadow (1883) included Parus, Aegithalos, Psaltriparus, Auriparus, Panurus, Regulus and several other genera in his family Paridae, but remarked that "Panurus does not belong to the Paridae, but perhaps to the Fringillidae." Stresemann (1923) stated Panurus, Paradoxornis and the Aegithalidae (Aegithalos, Psaltriparus and Psaltria) share certain cranial characteristics, nest structure and naked hatchings. While our study suggests that Panurus may have a close family level genetic distance with Aegithalos and Sitta, data of the Paradoxornithidae and the Timaliidae are needed to determine the phylogenetic relationships of Panurus.

We wish to express our deep appreciation to Dr. N. Kuroda, director of the Yamashina Institute for Ornithology, for giving us the opportunity to carry out this study. We are grateful to Dr. H. Morioka of the Department of Zoology, National Science Museum, for his critical comment and regarding of the manuscript. We also thank Asada Bird Shop, Ishida Animals and Birds Co., and Kunikazu Momose, Takashi Hiraoka, Miyako Tsurumi and Manabu Kajita of the Yamashina Institute for Ornithology for providing us with samples and support.

\section{LITERATURE CITED}

American Ornithologists' Union (AOU), 1998. Check-list of North American birds. 7th ed. American Ornithologists' Union, Washington, D. C.

Avise, J. C., Aquadro, C. F. \& Patton, J. C., 1982. Evolutionary genetics of birds. V. Genetic distances within Mimidae (mimic thrushes) and Vireonidae (vireos). Biochem. Genet. 20: 95-104.

Avise, J. C., Patton, J. C. \& Aquadro, C. F., 1980a. Evolutionary genetics of birds I. A relationships among North American thrushes and allies. Auk 97: 135-147. 
Avise, J. C., Patton, J. C. \& Aquadro, C. F., 1980b. Evolutionary genetics of birds. II. Conservative protein evolution in North American sparrows and relatives. Syst. Zool. 29: 323-334.

Avise, J. C., Patton, J. C. \& Aquadro, C. F., 1980c. Evolutionary genetics of birds. III. Comparative molecular evolution in New World warblers and rodents. J. Hered. 71: 303-310.

Barrowclough, G. F. \& Corbin, K. W., 1978. Genetic variation and differentiation in the Parulidae. Auk 95: 691-702.

Barrowclough, G. F., Corbin, K. W. \& Zink, R. M., 1981. Genetic differentiation in the Procellariiformes. Comp. Biochem. Physiol. 69B: 629-632.

Beaman, M., 1994. Palearctic birds. A checklist of the birds of Europe, North Africa and Asia, north of the foothills of the Himalayas. Harrier Publications, Stonyhurst.

Bell, L. J., Moyer, J. T. \& Numachi, K., 1982. Morphological and genetic variation in Japanese populations of the Anemonefish Amphiprion clarkii. Marine Biol. 72: 99-108.

Corbin, K. W., Sibley, C. G., Ferguson, A., Wilson, A. C., Brush, A. H. \& Ahlquist, J. E., 1974. Genetic polymorphism in New Guinea starlings of the genus Aplonis. Condor 76: 307-318.

Deignan, H. G., 1964. Subfamily Parurinae. Mayr, E. \& Paynter, R. A.(eds.) Checklist of birds of the world. 10:430-431. Museum of Comparative Zoology, Cambridge.

Gadow, H., 1883. Catalogue of the Passeriformes, or perching birds, in the collection of the British Museum. British Museum (Nat. Hist.), London.

Gill, F. B., Funk, D. H. \& Silverin, B., 1989. Protein relationships among titmice ( Parus). Wilson Bull. 101: 182-197.

Gutiérrez, R. J., Zink, R. M. \& Yang, S. Y., 1983. Genetic variation, systematic, and biogeographic relationships of some Galliform birds. Auk 100: 33-47.

Hellmayr, C. E., 1903. Paridae, Sittidae und Certhiidae. Das Tierreich 18: 1-255. R. Friedländer und Sohn, Berlin.

Hopkinson, D. A., Mestriner, M. A., Cortner, J. \& Harris, H., 1973. Esterase D: a new human polymorphism. Ann. Human Genet. 37: 119-137.

Kakizawa, R. \& Watada, M., 1985. The evolutionary genetics of the Estrildidae. J. Yamashina Inst. Ornith. 17: 143-158.

Kuroda, N., Kakizawa, R. \& Watada, M., 1990. Genetic divergence and relationships in fifteen species of Procellariiformes. J. Yamashina Inst. Ornith. 22: 114-123.

Kvist, L., Ruokonen, M., Orell, M. \& Lumme, J., 1996. Evolutionary patterns and phylogeny of tits and chickadees (genus Parus) based on the sequence of the mitochondrial cytochrome b gene. Ornis Fennica 73: 145-156.

Linné, C., 1758. Systema Naturae. 10th ed. Vol. 1. Laurentii Salvii, Stockholm.

Mayr, E. \& Amandon, D., 1951. A classification of recent birds. Am. Mus. Novit.1496: $1-42$.

Morony, J. J., Jr., Bock, W. J. \& Farrand, J. Jr., 1975. Reference list of the birds of the world. American Museum of Natural History, New York.

Nei, M., 1972. Genetic distance between populations. Amer. Nat. 106: 283-292.

Numachi, K., Nagahora, S. \& Iwata, M., 1979. Genetic demonstration of hybrids between chum and pink salmon in the northwest Pacific. Otsuchi Marine Res. Center Rep. 5: 87-102. (In Japanese.)

Numachi, K., Watada, M., Kakizawa, R., Kuroda, N. \& Utida, S., 1983. Evolutionary genetics of the Anatidae. Tori 32: 63-74.

Selander, R. K., Smith, M. S., Yang, S. Y., Johnson, W. E. \& Gentry, J. B., 1971. Biochemical polymorphism and systematics in the genus Peromyscus. I. Variation in the old-field mouse (Peromyscus polynotus). Studies in Genetics VI. Univ. 
Texas Publ. 7103: 49-90.

Shaw, C. R. \& Prasad, R., 1970. Starch gel electrophoresis of enzymes -A compilation of recipes. Biochem. Genet. 4: 297-320.

Sheldon, F. H. \& Gill, F. B., 1996. A reconsideration of songbird phylogeny, with emphasis on the evolution of titmice and their sylvioid relatives. Syst. Biol. 45: 473-495.

Sheldon, F. H., Slikas, B., Kinnarney, M., Gill, F. B., Zhao, E. \& Silverin, B., 1992. DNA-DNA hybridization evidence of phylogenetic relationships among major lineages of Parus. Auk 109: 173-185.

Slikas, B., Sheldon, F. H. \& Gill, F. B., 1996. Phylogeny of titmice (Paridae) : I. Estimate of relationships among subgenera based on DNA-DNA hybridization. J. Avian Biol. 27: 70-82.

Smith, J. K. \& Zimmerman, E. G., 1976. Biochemical genetics and evolution of North American blackbirds, family Icteridae. Comp. Biochem. Physiol. 53B: 319-324.

Sneath, P. H. A. \& Sokal, R. R., 1973. Numerical taxonomy. W.H. Freeman and Co., San Francisco.

Snow, D. W., 1967. Family Paridae. Paynter, R. A. (ed.) Check-list of birds of the world. 12: 70-124. Museum of Comparative Zoology, Cambridge.

Stresemann, E., 1923. Ueber die systematiche Stellung der Paradoxornithinae. Verhandl. Ornithol. Gesells. Bayern 15: 387-390.

Thielcke, G., 1968. Gemeinsames der Gattung Parus. Ein bioakustischer Beitrag zur Systematik. Beiheft Vogelwelt 1: 147-164.

Vaurie, C., 1950. Notes on some Asiatic titmice. Am. Mus. Novit. 1459: 1-51.

Vaurie, C., 1957. Systematic notes on Palearctic birds. No.27, Paridae: the genera Parus and Sylviparus. Am. Mus. Novit. 1852: 1-43.

Vaurie, C., 1959. The birds of the Palearctic fauna: Passeriformes. H. F. \& G. Witherby, London.

Watada, M., Jitsukata, K. \& Kakizawa, R., 1995. Genetic divergence and evolutionary relationships of the old and new world Emberizidae. Zool. Sci. 12: 71-77.

Watada, M., Kakizawa, R., Kuroda, N. \& Utida, S., 1987. Genetic differentiation and phylogenetic relationships of an avian family, Alcidae (auks). J. Yamashina Inst. Ornith. 19: 79-88.

Wolters, H. E., 1982. Die Vögelarten der Erde. Paul Parey, Hamburg. 
和文抄録 Japanese Summary of Papers in English

\section{ニホンジカが高密度に生息する森林の植生構造と鳥類群集}

(Breeding Bird Community and Vegetation Structure in a Forest with a High Density of Sika Deer. 48: 197-204)

\section{日野輝明}

\section{森林総合研究所関西支所 $\overline{\mathbf{T} 612-0855}$ 京都市伏見区桃山町}

ニホンジカが高密度に生息する紀伊半島の森林において, 慗殖期の鳥類群集と植生構造の調查を行っ た. 調查を行った森林はブナが基底面積で50\%近くを占め, それにオオイタャメイゲッやトゥヒなど が混じる針広混交林で, 高さ $1.5 \mathrm{~m}$ 以上の全樹木密度は1091本/ha，基底面積は $45 \mathrm{~m}^{3} / \mathrm{ha}$ であった. 植生の構造は，(1)低木密度が低い，(2)草本の密度と丈が低い，(3)枯死木の密度が高い，という特 徵があり，植被の量が森林の上層部から下層部まで全体にわたって少なかった．これらの植生の特徽 は，いずれあシカによる草本や樹木実生括よび樹皮の採食が大きな原因の一つであると考えられた。

94年から98年までの5年間, テリトリー・マッピング法によって, 調査地内で繁殖する鳥の種類と 密度を調べた結果, 平均種数は 20 , 平均番密度は $409 / 100 \mathrm{ha}$ で, 年によって大きな変化は見られず安

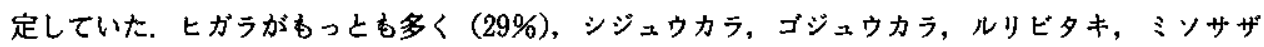
1の密度が高かった (8-10\%). 調查地において繁殖する烏の種数と密度は, シカの影䇾が小さいと 思われる森林で行われた報告と比较すると少なかった，これは，草本層に営巣する種が慗殖せず，ま た低木屬に営巣する鳥の種数と密度が低いためであり, 植生の特徽の(1)と(2)に関係づけられた. 一 方, 樹洞で営巣する鳥の種数と密度は他の森林と変わらず, これは植生の特徴(3)に関係づけられた。 従って, 森林に高密度に生息するニホンジカは, 採食によって植生を衰退させるばかりでなく, そこ に生息する鳥類群集の構造までも単純化していることが分かった。

\section{アイソザイムによる東アジア産シジュウカラ科鳥類 および近縁鳥類の類縁関係の研究}

(A Study on Genetic Differentiation and Phylogenetic Relationships among East Asian Titmice (family Paridae) and Relatives. 48: 205-218)

\section{太田紀子 ${ }^{1,2} \cdot$ 楠原征治 ${ }^{1}$ ・柿沢亮三 2}

\footnotetext{
1 新潟大学大学院自然科学研究科 $\bar{\top} 950-2181$ 新渴市五十嵐二の町 8050

2 㮩山階鳥類研究所 $=270-1145$ 我孫子市高野山115
} 
東アジアに生息するシジェウカラ科鳥類およびその近縁鳥類の類縁関係について調查するため, シ ジェウカラ属の 6 亜属 8 種 (シジュウカラ科)、エナガ属 2 種 (エナガ科), ゴジゥカララ属 1 種 (コ ジュウカラ科) およびヒゲガラ属 1 種（ダルマエナガ科）の計12種59個体について，15酳素・23遗伝 子座の電気泳動分析を行い, 遭伝的距離を求め, UPGMA法により系統樹を作成した.

その結果，東了ジア産のシジュウカラ科 8 種はコガラの系統 (コガラ), 七ガラの系統（七ガラ， キバラガラ, ヤマガラ), シジュウカラの系統 (シジェウカラ, キバラシジュウカラ), タイワンシジュ ウカラの系統（セボシカンムリガラ，タイワンシジュウカラ）の 4 つの系統に分かれた. セボシカン ムリガラはタイワンシジュウカラと遺伝的に近縁で, シジュウカラやキバラシジュウカラとは類縁が 遠かった．また，エナガ属，ゴジュウカラ属およびヒゲガラ属は科レベルの值としては比較的小さな 遗伝的距離で結びつき，このグルーブにシジュウカラ属が結びつく結果となった.

今回の実験では，コガラやセボシカンムリガラなど十分な個体数が得られなかった種があり，また， 鳥獣商からサンプルを入手したため，複数個体を扱った種でも標本の抽出に偏りが生じている可能性 がある. 今後, 複数の個体群からサンプルを収集し, 今回収集できなかった種にっいてあ実験を行う ことで, 東アジア産のシジュウカラ科鳥類の類緑関係がさらに明らかになると考えられる. 